\title{
Effect of Diluted Red Sea Water on Growth Behavior and Chemical Component of Moringa Plants
}

\author{
Sami A. Metwally ${ }^{\star}{ }^{\star}$, M. I. Ezzo ${ }^{2}$, Bedour H. Abou Leila ${ }^{3}$ \\ and Aboelfetoh M. Abdalla ${ }^{2}$

\begin{abstract}
${ }^{1}$ Department of Ornamental and Woody Trees, National Research Centre, Dokki, Cairo, Egypt. ${ }^{2}$ Horticultural Crops Technology Department, Agricultural and Biological Division, National Research Centre, Giza, Egypt Centre, Dokki, Cairo, Egypt.

${ }^{3}$ Department of Water Relations and Field Irrigation, National Research Giza, Egypt Centre, Dokki,
\end{abstract} Cairo, Egypt.

Authors' contributions

The authors equally contributed in all the article parts. The authors wrote, read and approved the final manuscript.

Article Information

DOI: 10.9734/ARRB/2021/v36i430364 (1) Dr. Marco Antonio Cavalcanti Garcia, Federal University of Juiz de Fora, Brazil.

(1) Hengshen Xie Jiangsu, China University of Mining \& Technol Reviewers: (2) Md. Jahirul Islam, Kangwon National University, Republic of Korea. Complete Peer review History: http://www.sdiarticle4.com/review-history/67522

Original Research Article

Received 11 February 2021

Accepted 21 April 2021

Published 28 April 2021

\begin{abstract}
Background: Moringa tree is a drought resistance tree, fast-growing, Moringa leaves, flowers and pods are a food source for human and animals. It is a rich source of calcium, iron and a good source of vitamins, B, A, C, amino acids. Shortage of water resources for irrigation especially in reclaimed soil considered is one of the great problems to cultivate traditional crops. Thus, nowadays the use of the non-traditional source of water, such as saline water is very important.

Results: The obtained data recorded that the lowest level of salinity $(4000 \mathrm{ppm})$ decreased plant height, fresh and dry weight of leaves, the stem fresh and dry weight, stem diameter recorded decreased. Increasing salinity levels up to $16000 \mathrm{ppm}$ high reduction was registered in the previously mentioned parameters except for leaves number. The interaction between salinity and proline concentration exhibited in most cases reduction in total chlorophyll. Carbohydrate content, protein, nitrogen\%, calcium\%, recorded reduction in most cases under saline condition and their interaction with proline. While, Sodium \%, $\mathrm{Cl}^{-}$percentage and proline content recorded increments in most cases under the previously mentioned circumstances.
\end{abstract}


Conclusion: The results were nearly ascending order with increasing of salinity level. Increasing salinity to $16000 \mathrm{ppm}$ decreased significantly the values of vegetative growth and almost all cases of chemicals constituents were reduced.

Keywords: Moringa oleifera; salnity; growth parameters proline; protein.

\section{ABBREVIATIONS}

ppm : Parts per million

Chl a : Chlorophyll a

Chl $b:$ Chlorophyll b

\section{INTRODUCTION}

Moringa tree (Moringa oleifera) is a drought resistance tree, fast-growing, deciduous tree or shrub with an average height of 12-meters at maturity. It is native to North Western India. Moringa is widely grown. However in other parts of old and new world tropics, including tropical Asia, many regions of Africa, and South and Central America. Moringa leaves, flowers and pods are a food source for human and animals. The flowers are a good nectar source for hanky and the seeds are a rich oil source for cooking and many parts of the plant have been used in medicinal preparation. The foliage and fruit pods are a rich source of calcium, iron and a good source of vitamins, B, A, C and amino acids methionine and cysteine. However, the ovendried flowers and leaves can be prepared, and young leaves and leaflets of old leave are prepared and eaten as green. In addition, the roots of moringa are a source of spice.

Shortage of water resources for irrigation especially in reclaimed soil considered is one of the great problems to cultivate traditional crops. Thus, nowadays, the use of non-traditional water sources, such as saline water, is crucial." the effect of saline water on growth and productivity of most plants is discussed by several authors $[1,2,3]$. (Termat and Munns., 1986 and Zhu et al.., 1997), Tiwari et al. [4], on cucumber, Hameed et al. [5] on wheat, Daneshmend et al. [6] on potato and Khalaf and Salih [7] on barley.

Consequently, it is important to choose the suitable concentration to irrigate this plant and also needs to choose the plants which survive against salt stress and improving the tolerance to salt stress.

The object of this study was to investigate the effect of red seawater salinity and role of selected amino acids proline to alleviate the harmful effect of seawater salinity stress on moringa.

\section{METHODS}

Two pot experiments were set up in green house of the Narional research Centre, Dokki, Cairo, in two successive growing seasons 2017 and 2018 to study the response of Moringa oleifera plants to grown under saline condition and the role of amino acid proline to alleviate the harmful effect of salinity stress on moringa plants. The treatments were as follows. Three concentrations of proline 200,400 and $600 \mathrm{ppm}$, and the concentration of salt in water were Tap water $0,4000,8000$,and $16000 \mathrm{ppm}$ were prepared by diluting Red seawater with fresh water in addition to tap water $250 \mathrm{ppm}$ as a control.Seawater analyses in List (1)were determined according to the methods described by Strickland and Parsons [8].

The experiments included four levels of salinity in combination with 3 levels of proline 200,400 and $600 \mathrm{ppm}$. Thus, the treatments included 13 treatments with7 replicates for each. For cultivation, pots of $50 \mathrm{~cm}$ diameter and $50 \mathrm{~cm}$ in depth were filled with a mixture of loamy and sandy soil $2: 1$ by volume $(30 \mathrm{~kg})$.

Four uniform seeds of moringa were sown on 146-2017.The seeds were obtained from Moringa Plants Production Association in National Research Centre. One month later, the plants were thinned to two plants per pot. The fertilizers were added at the usual and proper time.

Irrigation with diluted seawater in different concentrations was started two weeks after thinning (two irrigation by saltwater and next by freshwater alternatively). The plants were sprayed twice with proline the first was 30 days after thinning and the second was 15 days later.

After six months from sowing the first cut was taken and growth parameters were recorded in the vegetative phase to measure, (Plant height, leaves number, Stem diameter, leaves fresh 
weight, leaves dry weight, stem fresh weight and stem dry weight.

Total chlorophyll was determined according to the methods described by Saric et al. [9].

Carbohydrate $\mathrm{mg} / \mathrm{g}$ f. w. was determined according to Smith et al. [10].

Proline content was determined using fresh leaves according to Bates et al. [11].

Protein determines according to multiple the 6,25 constant number $x$ percentage of nitrogen accounted ( Protein $=6.25 \times \mathrm{xN} \%$ ) some important elements ( $\mathrm{N}, \mathrm{K}, \mathrm{Ca}, \mathrm{Na}$ and $\mathrm{Cl})$.

The second cut was taken after 6 months from the first to determine growth parameters.

Moringa leaves were harvested and dried in oven $60^{\circ} \mathrm{C}$ until complete drying and use a known weight $(0.2 \mathrm{~g})$ of dried sample. The samples were digested using concentrated sulfuric acid and perchloric acid (4:1) being, the mixture was heated for one hour until a clear solution was obtained. The digested solution was quantitatively transferred to a $50 \mathrm{ml}$ volumetric flask using distilled water and was used for element determinations according to [12].Potassium and Calcium (\%) were determined by the flame Photometer pfp7 according to [12].

Iron (ppm) was determined by using an Atomic Absorption Spectrophotometer, instrumentation laboratory aa/ae spectrophotometer 157 According to [13].

\subsection{Statistical Analysis}

Collected data were reported as means \pm SD and analyzed with COSTATV-63. The experimental design was a randomized complete block design. The main effects of salinity treatment and proline and their interaction were determined by two-way ANOVA with L.S.D was performed for comparison of means at 0.05, according to Snedecor and Cochrain [14].

\section{RESULTS}

\subsection{Effect of Salinity on Growth}

Table 2 shows the effect of salinity levels on growth parameters of Moringa oleiferaplants. It could be observed that the lowest level (4000 ppm) of salinity decreased plant height $19 \%$ less than the control, fresh and dry weight of leaves decrease 25.28 and $27.88 \%$ respectively. As for the stem fresh weight it recorded $23.28 \%$ less than the control. These results were insignificant in most cases. On the other hand, stem diameter and stem dry weight showed no reduction, compared with the control plants. In this respect, leaves number showed slight increments reached $23.71 \%$ over the control plants. Increasing salinity levels up to $16000 \mathrm{ppm}$ high reduction was registered in the previously mentioned parameters, except for leaves number.

The differences between treatments were not enough to reach the level of significance in most cases. These results mean that salinity affects plant growth adversely and the reduction might due to non-availability of water, disturbance in ions uptake or ion toxicity on the plant which alter the physiological and biochemical processes. In the second cut, plant height was not significantly affected meanwhile a drusting decrease was recorded in leaves number and leaves fresh weight and dry weight, compared with control plants. Meanwhile, the low levels $400 \mathrm{ppm}$ had no significant effect on both the fresh and dry weight of stem.

It is evident from Table 3 that moringa plants irrigated with diluted sea water from 4000 up to 16000 ppm showed a drastic decrease in leaves fresh and dry weight, stems fresh and dry weight, compared with the control plants. Under the effect of proline as foliar sprays, it has no appreciable effect on plant production. The highest stem fresh and dry weight were recorded when S1 (4000 ppm) interacted with P2 (400ppm). As for leaves fresh and dry weight, the highest fresh weight of leaves was registered through the interaction between S2+P2 (18.33g) while the highest leaves dry weight $(4.80 \mathrm{~g})$ was registered by $(\mathrm{S} 1+\mathrm{P} 2)$.

\subsection{Chlorophyll Content}

Results in Table 5 show that total chlorophyll $(a+b)$ was significantly increased with no clear differences as results of salinity treatments. The interaction between salinity and proline concentration exhibited in most cases a reduction in total chlorophyll concentration, especially in higher salinity levels.

\subsection{Carbohydrate Concentrations}

Carbohydrate content was significantly decreased under saline conditions, which might 
Table 1. Shows red seawater analyses, using principal component analyses

\begin{tabular}{|c|c|c|}
\hline Serial & Prosperities & Results \\
\hline $1-$ & $\mathrm{PH}$ & 7.25 \\
\hline $2-$ & Conductivity (Ms/cm) & 0.434 \\
\hline 3- & Total hardness as $\mathrm{CaCo} 3 \mathrm{ppm}$ & 22 \\
\hline 4- & $\mathrm{Ca}++\mathrm{ppm}$ & 2.3 \\
\hline 5- & $\mathrm{Mg}++\mathrm{ppm}$ & 4.0 \\
\hline $6-$ & Total alkaline as $\mathrm{CaCo} 3 \mathrm{ppm}$ & 10.2 \\
\hline 7- & $\mathrm{Na}+\mathrm{ppm}$ & 111 \\
\hline 8- & $\mathrm{K}+\mathrm{ppm}$ & 2.5 \\
\hline 9- & Cl- Chloride ppm & 104 \\
\hline $10-$ & Sulfate (So4) ppm & 201 \\
\hline $11-$ & $\mathrm{NH} 4$ ppm & 0.01 \\
\hline $12-$ & Nitrate No3-ppm & 2.71 \\
\hline 13- & Iron ppm & 0.05 \\
\hline $14-$ & Silica Sio2- ppm & 0.11 \\
\hline $15-$ & Total dissolved salts ppm & 233 \\
\hline
\end{tabular}

Table 2. Effect of different seawater salinity treatments and their interaction with pro line on the growth of Moringa oleifera (first cut)

\begin{tabular}{|c|c|c|c|c|c|c|c|}
\hline Treatments & $\begin{array}{l}\text { Plant height } \\
\text { (cm) }\end{array}$ & $\begin{array}{l}\text { Leaves } \\
\text { No. }\end{array}$ & $\begin{array}{l}\text { Stem diameter } \\
(\mathrm{mm})\end{array}$ & $\begin{array}{l}\text { Leaves fresh weight } \\
\text { (g) }\end{array}$ & $\begin{array}{l}\text { Leaves Dry weight } \\
\text { (g) }\end{array}$ & $\begin{array}{l}\text { Stem fresh weight } \\
(\mathrm{g})\end{array}$ & $\begin{array}{l}\text { Stem dry weight } \\
\text { (g) }\end{array}$ \\
\hline 0 & 167.00 & 7.00 & 0.90 & 14.33 & 4.16 & 48.66 & 8.00 \\
\hline S1 & 134.66 & 8.66 & 0.90 & 10.66 & 3.00 & 37.33 & 8.00 \\
\hline S2 & 124.66 & 8.00 & 0.88 & 15.66 & 5.00 & 32.33 & 7.66 \\
\hline S3 & 141.33 & 7.00 & 0.86 & 11.66 & 3.66 & 41.66 & 7.00 \\
\hline $\mathrm{S} 1+\mathrm{P} 1$ & 128.66 & 6.33 & 0.73 & 7.00 & 1.50 & 18.33 & 3.00 \\
\hline $\mathrm{S} 1+\mathrm{P} 2$ & 118.66 & 7.66 & 0.78 & 10.00 & 2.45 & 28.66 & 6.00 \\
\hline $\mathrm{S} 1+\mathrm{P} 3$ & 95.66 & 6.66 & 0.83 & 9.00 & 1.24 & 27.66 & 6.00 \\
\hline $\mathrm{S} 2+\mathrm{P} 1$ & 135.00 & 7.00 & 0.88 & 9.33 & 2.63 & 32.33 & 6.33 \\
\hline $\mathrm{S} 2+\mathrm{P} 2$ & 117.33 & 7.00 & 0.77 & 11.33 & 2.28 & 25.00 & 5.33 \\
\hline $\mathrm{S} 2+\mathrm{P} 3$ & 110.33 & 7.00 & 0.75 & 8.66 & 2.11 & 20.00 & 4.33 \\
\hline $\mathrm{S} 3+\mathrm{P} 1$ & 130.33 & 8.00 & 0.76 & 8.66 & 2.18 & 27.66 & 5.33 \\
\hline $\mathrm{S} 3+\mathrm{P} 2$ & 126.00 & 7.00 & 0.76 & 9.33 & 1.80 & 25.00 & 5.00 \\
\hline $\mathrm{S} 3+\mathrm{P} 3$ & 142.66 & 7.00 & 0.80 & 10.66 & 2.56 & 28.66 & 6.00 \\
\hline LSD & 14.68 & 1.75 & 0.07 & 3.36 & 1.29 & 10.63 & 2.25 \\
\hline
\end{tabular}

0: seeds untreated; S1: 4000ppm; S2: 8000 ppm; S3: 16000 ppm; P1: 200 ppm; P2:400 ppm; P3: 600 ppm 
Table 3. Effect of different seawater salinity treatments and the their interaction with proline on growth of Moringa oleifera (second cut)

\begin{tabular}{|c|c|c|c|c|c|c|c|}
\hline Treatments & $\begin{array}{l}\text { Plant height } \\
\text { cm }\end{array}$ & $\begin{array}{l}\text { Leaves } \\
\text { No. }\end{array}$ & $\begin{array}{l}\text { Stem diameter } \\
\mathrm{mm}\end{array}$ & $\begin{array}{l}\text { Leaves fresh weight } \\
\text { (g) }\end{array}$ & $\begin{array}{l}\text { Leaves Dry weight } \\
\text { (g) }\end{array}$ & $\begin{array}{l}\text { Stem fresh weight } \\
\text { (g) }\end{array}$ & $\begin{array}{l}\text { Stem dry weight } \\
\text { (g) }\end{array}$ \\
\hline 0 & 114.66 & 13.00 & 1.23 & 9.00 & 2.32 & 39.33 & 7.05 \\
\hline S1 & 114.66 & 7.66 & 0.96 & 6.00 & 0.72 & 39.33 & 7.79 \\
\hline S2 & 114.66 & 4.00 & 1.21 & 3.33 & 0.53 & 33.66 & 5.89 \\
\hline S3 & 111.33 & 4.66 & 1.26 & 4.00 & 1.22 & 34.66 & 5.96 \\
\hline $\mathrm{S} 1+\mathrm{P} 1$ & 91.00 & 5.00 & 0.92 & 2.00 & 0.93 & 24.66 & 6.92 \\
\hline $\mathrm{S} 1+\mathrm{P} 2$ & 97.33 & 7.00 & 1.20 & 5.00 & 2.35 & 40.33 & 7.10 \\
\hline $\mathrm{S} 1+\mathrm{P} 3$ & 104.00 & 6.00 & 1.15 & 4.66 & 0.68 & 35.33 & 6.89 \\
\hline $\mathrm{S} 2+\mathrm{P} 1$ & 77.33 & 5.66 & 1.15 & 3.00 & 0.33 & 22.33 & 4.17 \\
\hline $\mathrm{S} 2+\mathrm{P} 2$ & 77.00 & 7.00 & 1.01 & 7.00 & 0.62 & 22.66 & 3.44 \\
\hline $\mathrm{S} 2+\mathrm{P} 3$ & 94.33 & 7.00 & 1.10 & 5.00 & 0.45 & 34.66 & 6.22 \\
\hline $\mathrm{S} 3+\mathrm{P} 1$ & 66.33 & 4.00 & 0.91 & 2.33 & 1.65 & 14.66 & 2.63 \\
\hline $\mathrm{S} 3+\mathrm{P} 2$ & 76.00 & 3.66 & 0.85 & 4.33 & 1.37 & 15.00 & 2.86 \\
\hline $\mathrm{S} 3+\mathrm{P} 3$ & 59.50 & 4.33 & 0.95 & 2.00 & 2.09 & 13.66 & 2.49 \\
\hline LSD & 16.17 & 3.52 & 0.25 & 3.30 & 1.42 & 12.51 & 1.98 \\
\hline
\end{tabular}

0: seeds untreated; S1: 4000ppm; S2: 8000 Ppm; S3: 16000 ppm; P1: 200 ppm; P2:400 ppm; P3: 600 ppm

Table 4. Effect of different seawater salinity treatments and their interaction with proline on Moringa oleifera production from leaves and stems (first +second cuts) during one year (experimental time)

\begin{tabular}{|c|c|c|c|c|}
\hline Characters Treatments & Leaves fresh weight $(\mathrm{g})$ & Leaves Dry weight (g) & Stem fresh weight (g) & Stem dry weight (g) \\
\hline 0 & 23.33 & 6.48 & 87.99 & 15.05 \\
\hline S1 & 16.66 & 3.72 & 76.66 & 17.79 \\
\hline S2 & 18.99 & 5.53 & 65.99 & 13.55 \\
\hline S3 & 15.99 & 6.22 & 76.32 & 12.76 \\
\hline $\mathrm{S} 1+\mathrm{P} 1$ & 9 & 2.43 & 42.99 & 9.92 \\
\hline $\mathrm{S} 1+\mathrm{P} 2$ & 15 & 4.80 & 68.99 & 13.10 \\
\hline $\mathrm{S} 1+\mathrm{P} 3$ & 13.66 & 1.92 & 62.99 & 12.89 \\
\hline $\mathrm{S} 2+\mathrm{P} 1$ & 12.33 & 2.96 & 54.66 & 10.50 \\
\hline $\mathrm{S} 2+\mathrm{P} 2$ & 18.33 & 2.90 & 47.66 & 8.77 \\
\hline $\mathrm{S} 2+\mathrm{P} 3$ & 13.66 & 2.56 & 54.66 & 10.55 \\
\hline $\mathrm{S} 3+\mathrm{P} 1$ & 10.99 & 3.83 & 42.32 & 7.76 \\
\hline $\mathrm{S} 3+\mathrm{P} 2$ & 13.66 & 3.17 & 40.00 & 7.86 \\
\hline $\mathrm{S} 3+\mathrm{P} 3$ & 12.66 & 4.65 & 42.32 & 8.49 \\
\hline
\end{tabular}


Table 5. Effect of different seawater salinity treatments and their interaction with proline on some nutrient elements and chemical constituents on leaves of Moringa oleifera

\begin{tabular}{|c|c|c|c|c|c|c|c|c|c|}
\hline Treatments & $\mathbf{N} \%$ & $\mathbf{K} \%$ & $\mathrm{Na} \%$ & $\mathrm{Ca} \%$ & Cl ppm & Total chl. & Carbo. mg/gFW. & Protein & Proline \\
\hline 0 & 4.3 & 1.38 & 0.10 & 2.3 & 266 & 26.80 & 0.375 & 26.87 & 4.84 \\
\hline S1 & 1.5 & 1.48 & 0.33 & 2.6 & 266 & 33.30 & 0.151 & 9.37 & 5.54 \\
\hline S2 & 2.2 & 1.93 & 0.50 & 2.0 & 443 & 34.43 & 0.275 & 13.75 & 8.66 \\
\hline S3 & 3.1 & 1.80 & 0.11 & 2.4 & 89 & 33.53 & 0.151 & 19.37 & 7.78 \\
\hline $\mathrm{S} 1+\mathrm{P} 1$ & 0.2 & 1.85 & 0.48 & 2.3 & 89 & 17.76 & 0.585 & 1.25 & 5.99 \\
\hline $\mathrm{S} 1+\mathrm{P} 2$ & 3.8 & 1.63 & 0.13 & 1.9 & 621 & 29.73 & 0.526 & 23.75 & 7.17 \\
\hline $\mathrm{S} 1+\mathrm{P} 3$ & 2.7 & 1.93 & 0.28 & 2.0 & 89 & 30.43 & 0.495 & 16.87 & 6.70 \\
\hline $\mathrm{S} 2+\mathrm{P} 1$ & 0.1 & 1.90 & 0.60 & 2.2 & 18 & 27.16 & 0.496 & 0.625 & 7.67 \\
\hline $\mathrm{S} 2+\mathrm{P} 2$ & 1.9 & 2.05 & 0.43 & 2.2 & 905 & 27.16 & 0.728 & 11.87 & 8.87 \\
\hline $\mathrm{S} 2+\mathrm{P} 3$ & 2.8 & 1.93 & 0.68 & 2.3 & 799 & 24.83 & 0.791 & 17.50 & 7.28 \\
\hline $\mathrm{S} 3+\mathrm{P} 1$ & 3.1 & 1.93 & 0.68 & 3.6 & 621 & 27.30 & 0.707 & 19.37 & 8.43 \\
\hline $\mathrm{S} 3+\mathrm{P} 2$ & 3.1 & 1.88 & 0.60 & 3.1 & 372 & 28.83 & 0.729 & 19.37 & 9.81 \\
\hline $\mathrm{S} 3+\mathrm{P} 3$ & 3.4 & 1.93 & 0.50 & 3.6 & 266 & 35.46 & 0.720 & 21.25 & 7.48 \\
\hline LSD & - & - & - & - & - & 3.32 & 1.99 & - & - \\
\hline
\end{tabular}

0: seeds untreated; S1: 4000ppm; S2: 8000 ppm; S3: 16000 ppm; P1: 200 ppm; P2:400 ppm; P3: 600 ppm; Carbo.: Carbohydrate; Chl.: chlorophyll 
be attributed to the increments of soluble carbohydrates under salinity conditions. The interaction between salinity and proline concentration recorded significant increments in carbohydrates, especially at the concentration of 4000 ppm interacted with 200,400 and 600 ppm proline.

\subsection{Proline Content}

Proline concentrations were affected by salinity Table 5. The lowest proline content was registered by control plants and the highest values were recorded under 8000 ppm salinity. Increasing salinity level up to 16000 ppm proline registered a drastic decrease; which might be explained by the deleterious effect on plant metabolism due to the high salt concentrations (16000 ppm).

The interaction between salinity and proline concentrations reported the highest proline values when $4000 \mathrm{ppm}$ salinity interacted with $400 \mathrm{ppm}$ proline, followed in a descending order by 4000 ppm salinity interacted with 200 ppm concentration, while the lowest proline content was registered by increasing salinity levels up to 16000 ppm.

\subsection{Protein Content}

Irrigation with different salinity levels increased protein content, in the leaves, stems and roots, as compared to untreated plants.

A drastic decrease in protein content was recorded under saline conditions. The lowest value was registered by salinity $4000 \mathrm{ppm}$ $(9.37 \%)$ and The interaction between 8000 ppm salinity and proline 200 ppm concentrations $(0.625 \%)$, compared with control and other treatments.

\subsection{Nutrient Contents}

Results in Table 5 show that in generally treated moringa plants with all saline concentrations and their interaction with proline treatments registered a decrease in leaves nitrogen content. The lowest values were recorded under 4000 ppm salinity interacted with 200 ppm proline concentration the value reached $(0.1 \%)$, followed by 16000 ppm interacted with 200 ppm proline concentration and reached $(0.2 \%)$.On the other hand, the previously mentioned treatments ((all saline concentrations and its interaction with proline treatments) recorded increments on potassium and sodium percentage. The highest percentage of potassium was recorded under 8000 ppm salinity interacted with 400 ppm proline and reached (2.05\%), followed by 8000 and/ or 4000 ppm salinity interacted with 200 and/or 600 ppm proline which reached (1.93\%).

Sodium \% was increased in general under saline conditions, compared to control plants. The sodium percentage reached its highest values $(0.68,0.68$ and $0,60 \%)$, compared with the control plants When 8000 ppm and/or 4000 ppm interacted with proline 600 and (200 and/or400) ppm, respectively.

As for calcium percentage in leaves under saline conditions, it was decreased in most cases. On the contrary, 4000 ppm salinity interacted with all proline concentrations treatments increased up to $(3.6,3.1$ and $3.6 \%$ ), compared with control and other treatments.

Calcium ppm in leaves was increased under saline conditions in most cases, 8000 ppm salinity recorded (905 ppm) Cl when interacted with 400 ppm proline while increasing proline concentration up to $600 \mathrm{ppm}$, the values were decreased to $(799 \mathrm{ppm})$ in leaves. The data also revealed that $8000 \mathrm{ppm}$ salinity recorded the lowest $\mathrm{Cl}(18 \mathrm{ppm})$, when interacted with the least proline concentration.

\section{DISCUSSION}

Reduction in growth parameters under saline could be attributed to the reduction in cell division and cell elongation and reduction in dry weight might be due to the considerable decrease in photosynthetic processes or a reduction in water absorption.Salt stress leads to stomata closure which inhabits the availability of $\mathrm{CO}_{2}$ fixation and increases the generation of reactive oxygen species and induced oxidative stress. Thus, Ros interacts with many cellular components and causes damage to the membrane. The damage effect of salinity on growth was studied by different investigators, increase soil salinity causes nutrient imbalance due to the accumulation of toxic elements and reduces water infiltration [1].

High salt stress directly or indirectly inhibits cell division, enlargement in the growing tissues of roots, stem and leaves, may lead to leaf burn and defoliation, and reduced plant height, dry weight, number of leaves and number of flowers. The leaves die sooner in a more salt-sensitive 
variety because salts arrive faster or because cells unable to compartmentalize the salts in vacuoles $[2,3]$.

High salt concentration in the external solution and even low salinity levels has physiological effects on mineral uptake by roots and plant cells produce several deleterious consequences and also, cause an ionic imbalance (Termat and Munns.1986).

Generally, salinity and water stress (drought) have effects on morphological, physiological, anatomical and biochemical on plant growth. In this respect, the deleterious effect of salinity on the plant was reported by Tiwari et al. [4], on cucumber, Hameed et al. [5] on wheat, Daneshmend et al. [6] on potato and Khalaf and Salih [7] on barley. Munns and Tester [15] indicated that the inhibition in plant growth by salinity might be due to the bad effects of toxic ions mainly $\mathrm{Na}+$ and $\mathrm{Cl}-\mathrm{Kaydan}$ and Okut [16], Abdul Qados [17] and Haile and Kang [18], obtained similar results; they returned such reductions in growth to decrease in water availability by plant roots, which led to the disturbance in the water status of plant's tissues and metabolic processes, leading to reductions in meristematic activity and cell size. It also caused an increment in respiration rate due to the higher energy requirements.

The increase in $\mathrm{Chl} \mathrm{a,} \mathrm{Chl} \mathrm{b} \mathrm{and} \mathrm{total} \mathrm{chlorophyll}$ might be due to the increase in thickness of palisade and spongy tissues of $J$. curcas leaves. Which were the chlorenchymatous mesophyll tissue, which contains numerous chloroplasts and considered the principal site for photosynthesis [19] or might be due to reduced leaf water content due to the effect of salinity [20]. These results were in accordance with the findings of Petersen et al. [21] and James et al. [22]. This increment in chlorophyll concentration could be attributed to the availability of higher levels of amino acids in treated plants that induced an increase in chlorophyll content [23].

Increasing salinity level resulted in either increases or decreases in total soluble sugar percentage, being more pronounced under the severe salinity stress, compared with control These results were in line with those recorded by Devitt et al. [24]; Hernandez et al. [25]; Rai et al. [26]; Yamad et al. [27] and Abd El-Samad et al. [28]. The accumulation of compatible solutes such as soluble sugar might help to maintain the relatively high turgidity (RWC), which was necessary in osmo regulation needed for plant growth and cellular functions [28]. Furthermore, Sacher and Staples [29] reported that increasing sugar levels relative to control in salt stressed plants might contribute to the turgid maintenance.

From the results irrigation with different salinity levels increased proteincontent Hernandez et al. [25] pointed that cellular osmotic adjustment occurs in response to stress via an active or passive accumulation of salts. It has been assumed that salt stress enhanced the production and reduction of protein which causes osmotic adjustment [30]. The response of different plants to salt stress depends on the degree of their tolerance and on type, level and duration of osmotic substrate as reported by Hishida et al. [31] and Hossain et al. [32]. Increasing salt concentration decreased protein content such reduction might be due to protein hydrolysis Klyshev and Rakove [33], disturbance in cation balance Soakvan and petrouan [34], increase in hydrolyzing enzyme such as protease Garg and Garg [35] and Ebad et al. [36]. These results hold true with the finding of Glori Irma and Lilia [37].

In general treated moringa plants with all saline concentrations and its interaction with proline treatments registered a decrease in leaves nitrogen content, Sodium \% was increased, As for calcium percentage in leaves under saline conditions, it was decreased in most cases. In this respect, the studied mineral ions $\mathrm{K}+$ and $\mathrm{P}$ were decreased while $\mathrm{Na}+\mathrm{Ca}++$ and $\mathrm{Mg}++$ increased with salinity. This phenomenon is important in osmotic adjustment and turn salt tolerance, since it leads to increase osmotic pressure of the plant. In this respect Treeby and Van Steveninck [38] proposed that phosphorus does not contribute to osmotic adjustment and instead accumulates in cell walls of stressed plants. These results are in agreement with Ashish et al. [39]. The positive increase in $\mathrm{Na}+$ could be explain in Marshners [40] classification of the ability of plants to substitute $\mathrm{Na}+$ with $\mathrm{K}+$. In this classification, Marschner divided plants into four groups, A, B, C and D depending upon whether $\mathrm{K}+$ is mostly exchangeable with $\mathrm{Na}+$. Sodium has a positive effect on growth in $A$ and $B$ plants (mostly salt tolerance plants). The increase in $\mathrm{Ca}++$ concentration is important for preserving membrane integrity [41] signaling in osmoregulation [42] and influencing $\mathrm{K}+/ \mathrm{Na}+$ selectivity [43]. However salt tolerance of Jotropja curcas at the whale plant level is 
dependence on integration of different attributes that may help alleviate $\mathrm{NaCl}$ stress. Al Othaimen [44] on paper plants indicated that increasing $\mathrm{NaCl}$ salinity concentration tended to increase the inorganic mineral elements (potassium, Nitrogen, Sodium calcium and chloride contents compared with control plants.

\section{CONCLUSION}

Increasing salinity to $16000 \mathrm{ppm}$ decreased the values of vegetative growth significantly, and almost all cases of chemicals constituents were reduced. The interaction exhibited in most cases reduction on chemical constituents especially in higher salinity levels. While, Sodium \%,Clpercentage and proline content recorded increments in most cases under the previous mentioned circumstances.

\section{CONSENT}

It is not applicable.

\section{ETHICAL APPROVAL}

The manuscript does not contain studies involving human participants, human or animal data, and animal or human tissue.

\section{AVAILABILITY OF DATA AND MATERIALS}

All data generated or analyzed during this study are included in this manuscript.

\section{ACKNOWLEDGEMENTS}

The authors would like to thank National Research Centre, for their facilitates during this work.

\section{COMPETING INTERESTS}

Authors have declared that no competing interests exist.

\section{REFERENCES}

1. Munns R. Physiological processes limiting plant growth in saline soil: Some dogmas and hypotheses. Plant, Cell \& Environment. 1993;16:15-24.

2. Bass $R$, Nijssen $H M$, Vanden $T J$, Warmenhoven MG. Yield and quality of carnation (Dianthus caryophyllus L.) and gerbera (Gerbera jamesonii L.) in a closed nutrient system as affected by sodium chloride. Scientia Horticulturea. 1995;61(34):273-284.

3. Sonnevedt $E$, Vam den Brink $C E$, Tertoolen LG, Van der Burg B. Retinoic acid hydroxylase (CYP26) is a key enzyme in neuronal differentiation of embryonal carcinoma cells. Dev Biol. 1999;213(2):390-404.

4. Tiwari JK, Munshi AD, kumar R, Pandey RN, Arora A, Bhat JS, Sureja AK. Effect of salt stress on cucumber $\mathrm{Na}^{+} / \mathrm{K}^{+}$ratio, osmolyte concentrations, phenols and chlorophyll content. Acta Physiol, Plant. 2010;32:103-114.

5. Hameed A, Bibi N, Akhter J, Igbal N. Different changed in antioxidant, proteases and lipid peroxidation in flange leaves of wheat genotypes under different levels of water deficit conditions. Plant Physiol Biochem, 2011;49:178-185.

6. Daneshmand F, Arvin MJ, Kalantan YM. Physiological responses of $\mathrm{NaCl}$ stress in three wild species of potato in vitro. Acta Physiol Plant. 2010;32:91-101.

7. Khalaf $A F$, Salih $A B$. Improving drought and salinity tolerance in barley by application of salicylic acid potassium mitrate. Journal of the Saudi of Agricultural Science. 2014;45-55.

8. Strickland JDH, Parsons TR. A practical handbook of seawater analysis bulletin No. 167;1968.

9. Saric MR, Kastrori CT, Gerir I, Vasiverzit NS, Praktikum IB, Beogard HA. 1967; 215.

10. Smith FM, Dubois M, Gilles KS, Hamilton DK, Rebers PA. Colormetric methods for determination of sugars and related substances. Annal Chem. 1956;28:350356.

11. Bates LS, Waldren RP, Teare ID. Rapid determination of free proline of water stress studies. Plant and Soil. 1973;39: 205-207.

12. Cottenie A, Verloo M, Kiekens L, Velghe G, Camerlynck R. Chemical analysis of plant and soil. laboratory of analytical and agro chemistry, State Univ. Ghent. Belgium. 1982;100-129.

13. Ziya KO, Acar MU, Ilimb M. Determination of lead, copper, zinc magnesium, calcium and iron in fresh eggs by atomic absorption spectrometer. Food Chemistry. 2002;76(1):107-11.

14. Snedecor GW, Cochran WG. Statistical methods, 11th ed. lowa state Univ. press, Ames, lowa, USA; 1990. 
15. Munns R, Tester M. Mechanism of salinity tolerance. Annual Review of Plant Biology. 2008;59:651-681.

16. Kaydan D, Okut MY. Effects of salicylic acid on the growth and some physiological characters in salt stressed wheat (Triticum aestivum L.). Tarim Billimleri Dergisi. 2007;13(2):114-119.

17. Abdul Qados AM. Effects of salicylic acid on growth, yield and chemical contents of pepper (Capsicum annuum L) plants grown under salt stress conditions. International Journal of Agriculture and Crop Science. 2015;8(2):107-113.

18. Haile $M$, Kang WH. Growth and physiological responses of coffee (Coffea arabica L.) seedlings irrigated with diluted deep sea water. African Journal of Agricultural Research. 2018;13(7):311320.

19. Xu H, Tam NF, Zan QJ, Bai M, Shin PK, Vrijmoed LL. Effects of salinity on anatomical features and physiology of a semi-mangrove plant Myoporum bontioides. Mar. Poll. Bull. 2014;85:738746.

DOI:10.1016/j.marpolbul.2014.04.003

20. Yuwono T, Handayani D, Soedarsono J. The role of osmotolerant rhizobacteria in rice growth under different drought conditions. Aust. J. Agr. Res. 2005;56: 715-721.

21. Petersen KK, Willumsen J, Kaack K. Composition and taste of tomatoes as affected by increased salinity and different salinity sources. J. Hort. Sci. 1998;73:205215.

22. James SA, Smith WK, Vogelmann EC. Ontogenetic differences in mesophyll structure and chlorophyll distribution in Eucalyptus globulus ssp. globulus (Myrtaceae). Am J Bot.1999;86:198-207.

23. Awad MM, Abd El-Hameed AM, Shall ZS. Effect of glycine, lysine and nitrogen fertilizer rates on growth, yield and chemical composition of potato. J Agric Sci Mansoura Univ. 2007;32(10):85418551.

24. Devitt DA, Ktolzy L, Labanauskas CK. Impact of potassium, sodium and salinity on the protein and free amino acid content of wheat grain. Plant Soil. 1987;103:101109.

25. Hernandez S, Deleu C, Larrher F. Proline accumulation by tomato tissue in response to sailinty, 2000;6:551-557.
26. Rai VK. Role of amino acids in plant responses to stress. Biol Plant. 2002;45: 471-478.

DOI:

http://dx.doi.org/10.1023/A:102230822975 9

27. Yamada M, Morishita H, Urano K. Effects of free proline accumulation in petunias under drought stress. J. Exp. Bot. 2005;417:1975-1981.

28. Abd El-Samad HM, Shaddad MA, Barakat $\mathrm{N}$. Improvement of plants salt tolerance by exogenous application of amino acids. Journal of Medicinal Plants Research. 2011;5(24):5692-5699.

29. Sacher RF, Staples RC. Inositol and sugars in adaptation of tomato to salt. Plant Physiol. 1985;77:206-210.

30. Highkin HR, Frankel F. Studies of growth and metabolism of barley mutant lacking chlorophyll. Plant Physiol. 1962;37:814820.

31. Hishida $F$, Ascencio V, Fujiyama $H$, Orduño-Cruz A, Endo $\mathrm{T}$, LarrinagaMayoral JÁ. Differential responses of Jatropha species on growth and physiological parameters to salinity stress at seedlings plant stage. Communications in Soil Science and Plant Analysis Tandfonline.com/doi/pdf, on line; 2013.

32. Hossain M, Fujita M. Evidence for a role of exogenous glycine betaine and proline in antioxidant defense and methyl glyoxal detoxification systems in mung bean seedlings under salt stress. Physiology and Molecular Biology of Plants. 2010;16:19-29.

33. Klyshev LK, Rakova NM. Effect of salinzation of the substrate on protein composition of the roots in peas. Tr. Inst. Bot. Akad Kaz.SSR. 1964;20:156. [c.f.Biol.Abst.,1966,34164].

34. Soakvan RC, Petrouan GP. The effect of soil salinity on level of nucleic acids and nitrogenous substances in grape leaves. Fiziol. Ras. 1964;11(4):68. [c.f.Biol.abst. 1965, 30012].

35. Garg BK, Garg OP. Sodium Carbonate and bicarbonate induced change in growth, chlorophyll, nucleic acids and protein contents in leaves of Pisum sativum. Photosynthetic, 1980;14(4):594.

36. Ebad FA, Khalaf SH Ashoub AH, El-Goaly FM. Kinetin and cycocel effect on germination, growth and some metabolic products of soybean and maize growth 
under saline conditions. Annals of Agric. Sci, Moshtohor. 1987;25:1338.

37. Glori Irma AA, Lilia Mcaraz M. Salinity effects on protein content, lipid peroxidation, pigments and protine in paulwnia (Siebold and Zuccarini) and paulownia fortueni (Somann and Hemsley) grown In vitro. Electronic Journal of Biotechnology. 2010;13:(5).

38. Treeby MT, Van Steveninck RF. Effect of salinity and phosphate onion distribution in lupin leaflets. Plant Physiol. 1988;73:317.

39. Ashish DP, Nilesh SP, InduBhushan $P$, Amarnath P. Growth, water status and nutrient accumulation of seedlings of Jatropha curcas L. (euphorbiaceae) in response to soil salinity. Anals de Biologia, 2010;32:59-71.

40. Marschner $\mathrm{H}$. Mineral nutrition of higher plants; London: Academic Press.1995;889.
41. Rengl Z. The role of calcium in salt toxicity. Plant Cell and Environment. 1992;15:625632.

42. Mansfield T, Hetherington A, Atkinson C. Some aspects of stomatal physiology. Aannual Review of Plant Physiology and Plant Molecular Biology. 1990;41: 52-75.

43. Cramer GR, Lynch J, Lauchli A, Polito US. Influx of $\mathrm{Na}^{+}, \mathrm{K}^{+}$and $\mathrm{Ca}^{++}$into roots of salt stressed cotton seedlings. Effect of supplemenental Ca. Plant Physiology. 1987;83:510-516.

44. Al Othaimen HS. Improve the salinity stress by using ascorbic acid on germination, growth parameters, water relations, organic and inorganic components of Sweet Paper (Apsicum annum,L.)Plant. Journal of advances in agriculture. 2015;4(1).

(C) 2021 Metwally et al.; This is an Open Access article distributed under the terms of the Creative Commons Attribution License (http://creativecommons.org/licenses/by/4.0), which permits unrestricted use, distribution, and reproduction in any medium, provided the original work is properly cited. http://www.sdiarticle4.com/review-history/67522 